\title{
Ku80 interaction with apurinic/apyrimidinic sites depends on the structure of DNA ends
}

\author{
A. A. Kosova ${ }^{1,2}$, S. N. Khodyreva ${ }^{1,2}$, O. I. Lavrik ${ }^{1,2}$ \\ ${ }^{1}$ Institute of Chemical Biology and Fundamental Medicine, Siberian Branch of the Russian Academy of Sciences \\ 8, Akademika Lavrentieva Ave., Novosibirsk, Russian Federation, 630090 \\ ${ }^{2}$ Novosibirsk State University \\ 2, Pirogova Str., Novosibirsk, Russian Federation, 630090 \\ kosova.anastasiya@gmail.com
}

\begin{abstract}
Aim. The identification of a protein from human cell extract which specifically interacts with the apurinic/apyrimidinic (AP) site in the partial DNA duplex containing 5'- and 3'-dangling ends (DDE-AP DNA) and mimicking clustered DNA damage. Methods. The Schiff base-dependent cross-linking of a protein to AP DNA (borohydride trapping), MALDI-TOF-MS, chromatography, and gel electrophoresis. Results. A human cell extract protein which forms a major covalent adduct with the AP DNA duplex with dangling ends was identified as the Ku80 subunit of Ku antigen by peptide mass mapping based on MALDI-TOF-MS data. The Ku antigen purified from the HeLa cell extract was shown to form the covalent adducts with the same mobility as observed in cell extracts. Conclusions. The Ku80 subunit of Ku antigen can specifically interact with AP DNA forming the Schiff base-mediated adducts which electrophoretic mobility depends on the structure of DNA ends. The difference in electrophoretic mobility can be caused by the cross-linking of AP DNA to distinct target amino acids that appears to reflect unequal positioning of AP DNAs in the complex with Ku antigen.
\end{abstract}

Keywords: Ku antigen, apurinic/apyrimidinic site, protein-DNA cross-linking, clustered DNA damages.

Introduction. The abasic (AP) sites are among the most frequent DNA damages. Up to $50000 \mathrm{AP}$ sites arise in a mammalian cell per day [1] as a result of spontaneous hydrolysis of $\mathrm{N}$-glycosidic bond or under the action of DNA glycosylases during the base excision repair [2]. If unrepaired, the AP sites are mutagenic and cytotoxic. The repair of AP sites in clustered DNA damages presented by combinations of the AP sites, oxidized bases and single strand breaks within 1-2 turns of DNA helix is of particular interest [3]. Such lesions arise in DNA under the action of ionizing radiation or radiomimetic drugs.

The cross-linking of proteins to a baseless deoxyribose in DNA via reduction of a Schiff-base intermediate is often called «borohydride trapping» (BHT). BHT in combination with mass spectrometry has been used in a proteomic approach to identify the human pro-

(C) Institute of Molecular Biology and Genetics, NAS of Ukraine, 2014 teins reactive to AP sites [4-6]. The set of DNA duplexes containing the AP site in the middle of 32-mer oligonucleotide and different structural features has been used. With all AP DNA, except DNA with both 5'- and 3'-dangling ends of $8 \mathrm{nt}$ (DDE-AP DNA), the predominant products of cross-linking were of the same electrophoretic mobility (an apparent molecular mass of 90 $\mathrm{kDa}$ ). The protein cross-linked to the AP DNA duplex with blunt ends (BE-AP DNA) was identified as the $\mathrm{Ku} 80$ subunit of $\mathrm{Ku}$ antigen [4]. Ku antigen consisting of two subunits with molecular masses about $70 \mathrm{kDa}$ $(\mathrm{Ku} 70)$ and $83 \mathrm{kDa}(\mathrm{Ku} 80)$ is a eukaryotic DNA-binding component of DNA-dependent protein kinase. The main function of $\mathrm{Ku}$ antigen is participation in the double-strand break repair by non-homologous end joining [7]. In the present work we identified the protein which specifically interacts with DDE-AP DNA forming the product with an apparent molecular mass of $100 \mathrm{kDa}$. 
Materials and methods. Chromatographic fractionation of cell extract proteins. HEK 293 cell extract prepared as described elsewhere [8] was diluted 4 times with the buffer containing $50 \mathrm{mM}$ Tris- $\mathrm{HCl}(\mathrm{pH} \mathrm{8.0)}$, $1 \mathrm{mM}$ EDTA, $1 \mathrm{mM}$ DTT, $0.025 \% \mathrm{NP}-40$ and was applied to a heparin-sepharose column. After washing with the same buffer, the proteins were eluted with linear gradient of $\mathrm{NaCl}(0.05-1 \mathrm{M})$ in the same buffer. The presence of a target protein in the fractions was determined by BHT. The fractions were concentrated and supplemented with glycerol (final concentration of $10 \%$ ).

Borohydride trapping and MALDI-TOF-MS analysis. All procedures were carried out as described previously [4] with a few exceptions. The concentration of AP DNA in the reaction mixtures was $0.2 \mu \mathrm{M}$. The preparative cross-linking for MALDI-TOF-MS analysis was performed using a fractionated cell extract enriched in the target protein by chromatography on heparin-sepharose. The peptides derived from the cross-linked protein were additionally purified on Zip-tip C-18 prior to the MS analysis.

Purification of Ku antigen. Ku antigen was purified from the HeLa cell extract prepared as described in [8] by ammonium sulfate fractionation (45-65\% of saturation) followed by the successive chromatographies on DEAE-support («BioRad», USA), Q-sepharose («GE Healthcare») and DS-DNA-cellulose («ICN», USA).

Results and discussion. The BHT experiments using the DDE- and BE-AP DNAs and several human cell extracts, including the HeLa and HEK 293 cells, reveal nearly identical patterns of the cross-linked proteins. Data for HeLa cell extract are shown in Fig. 1.

For identification of the target protein we used the fraction of HEK 293 cell extract proteins eluted from heparin-sepharose at 450-500 $\mathrm{mM} \mathrm{NaCl}$ and enriched in the target protein. Use of the enriched extract ensures the yield of target protein cross-linking with AP DNA and reduces the likelihood of sample contamination with the proteins nonspecifically bound to DNA. After the electrophoretic separation of the protein covalent adducts with biotinylated DNA bound to streptavidin-coated beads, the gel was stained by Coomassie Brilliant Blue R-250 (Fig. 2, A) and autoradiography was carried out (Fig. 2, $B)$. Five well-defined protein bands with apparent molecular masses from 100 to $70 \mathrm{kDa}$ (Fig. 2, C) were excised from the gel and subjected to in-gel trypsin digestion.

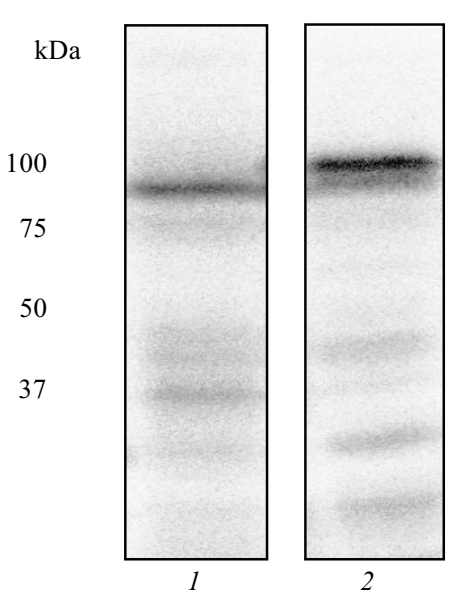

Fig. 1. Borohydride trapping of $\mathrm{HeLa}$ cell extract proteins with ${ }^{32} \mathrm{P}$ labeled AP DNA: 1 - BE-AP DNA; 2 - DDE-AP DNA

$A$
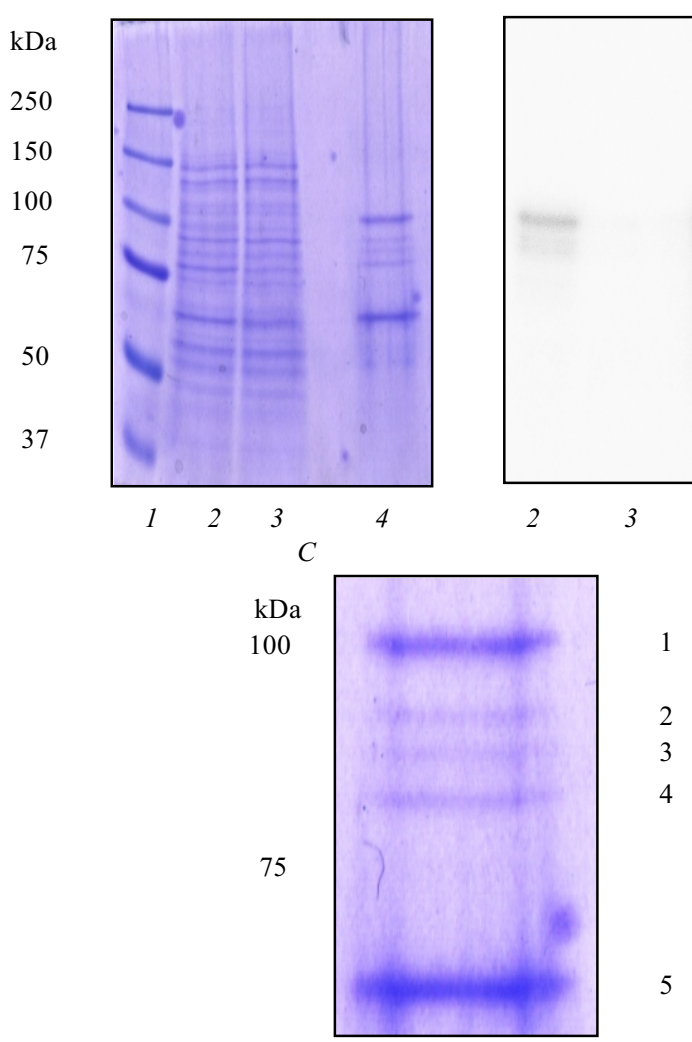

Fig. 2. Purification of cell extract protein(s) cross-linked with AP DNA: $A$ - Coomassie Brilliant Blue R-250 stained gel ( 1 - molecular weight markers; 2 - an aliquot $(25 \mu \mathrm{l})$ of reaction mixture before incubation with streptavidin-coated beads; 3 - an aliquot $(25 \mu \mathrm{l})$ after incubation (unbound proteins); 4 - covalent adducts and proteins bound to beads); $B$ - autoradiograph of the gel from Fig. 2, $A$; $C$-zoomed fragment of Fig. 2, $A$, lane 4

The bands $\mathrm{N}$ 1-4 have the matching radioactive bands, thus corresponding to the protein-DNA covalent adducts. 
Table 1

Parameters of the first rank candidates for the samples $N$ 1-5

\begin{tabular}{c|c|c|c|c|c}
\hline Sample number & First rank candidate & Molecular mass, Da & MOWSE score & Mass values matched & Protein sequence coverage, \% \\
\hline 1 & Ku80 & 82652 & 176 & 19 & 27 \\
2 & Ku80 & 82652 & 149 & 33 & 38 \\
3 & Ku80 & 82652 & 67 & 13 & 17 \\
4 & N-terminal proteolytic fragment of Ku80 & 64064 & 85 & 19 & 35 \\
\hline
\end{tabular}

Table 2

Observed masses in MALDI-TOF mass spectrum of the sample N 1 which correspond to theoretical peptides of Ku80

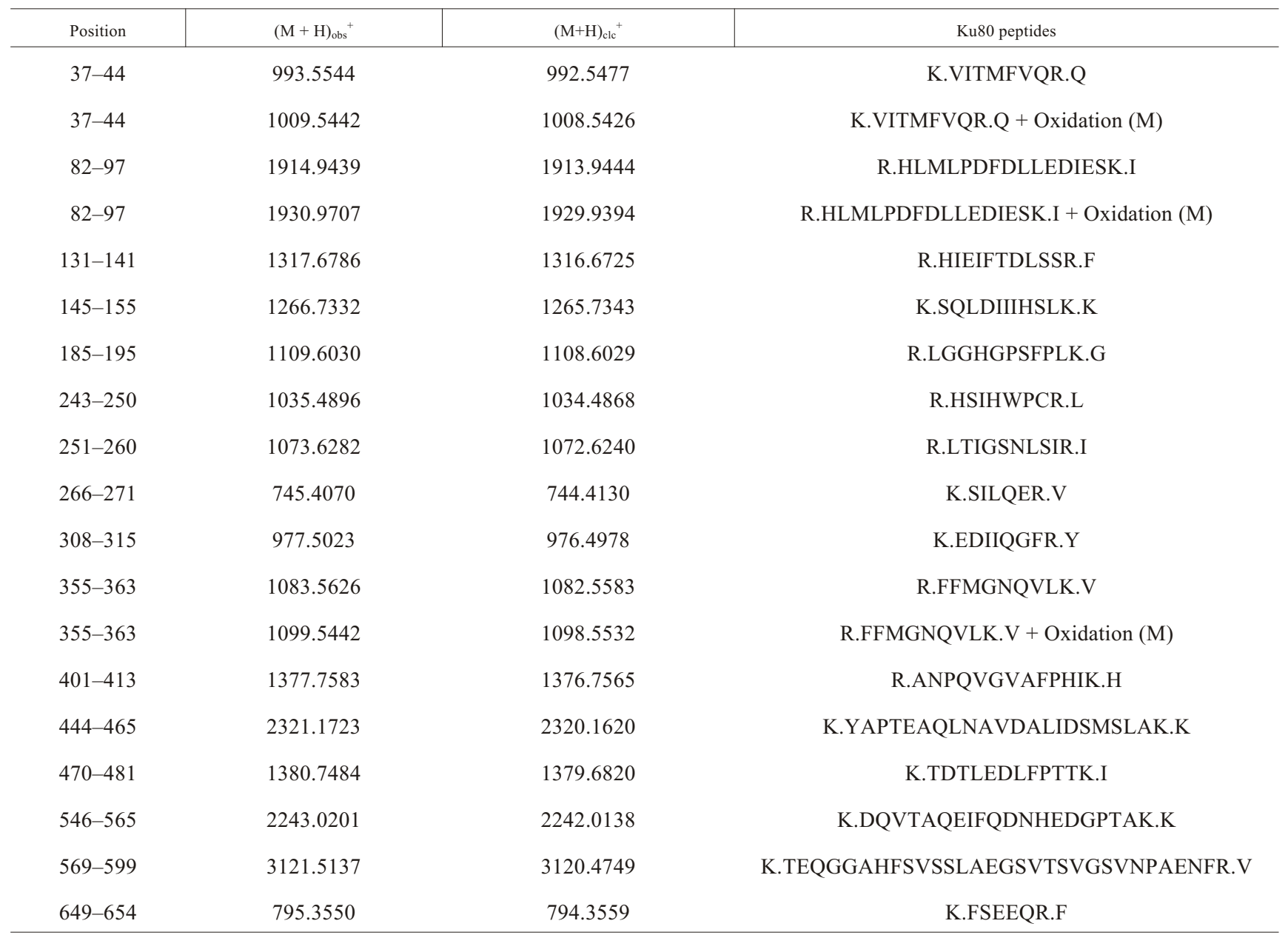

Furthermore, the $100 \mathrm{kDa}$-band has the highest intensity with the both methods of visualization. Peptides were analyzed by MALDI-TOF-MS and data were searched against a database.

The first rank candidates for all the samples with their scores, the number of the matched peptide mass values and the protein sequence coverage are shown in Table 1.
Obviously, Ku80 forms several covalent adducts with DDE-AP DNA. Ku70 is retained on the beads due to the strong interaction with $\mathrm{Ku} 80$ [4, 9].

The data for the matching peptides in the sample $\mathrm{N}$ 1 are shown in Table 2. Interestingly, the set of Ku80 peptides identified in this work is almost overlapped with those obtained in the other works $[4,10]$. This is 


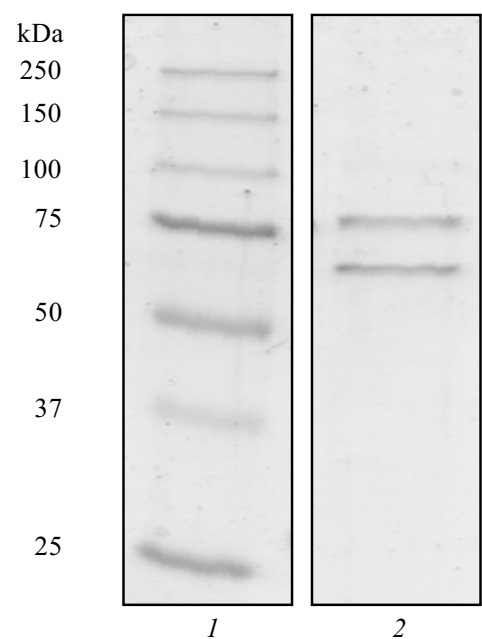

Fig. 3. Purified $\mathrm{Ku}$ antigen (Coomassie Brilliant Blue R-250 stained gel): 1 - molecular weight markers; 2 - purified $\mathrm{Ku}$ antigen $(0.6 \mu \mathrm{g})$

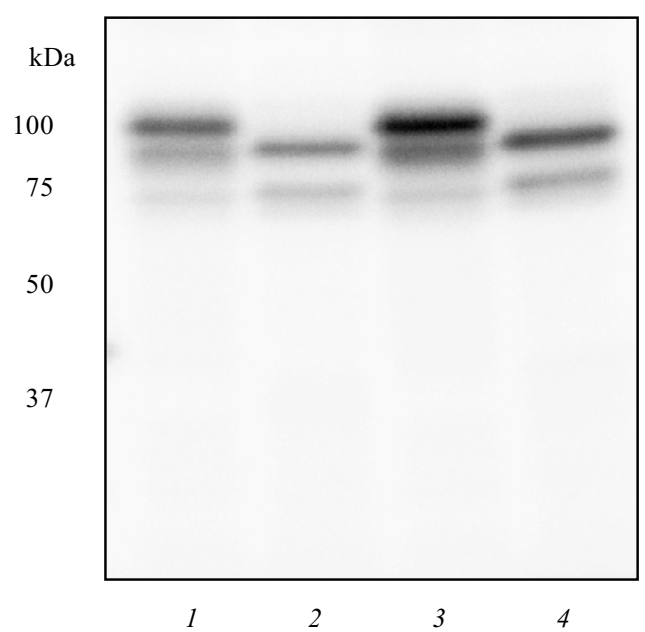

Fig. 4. Borohydride trapping of purified $\mathrm{Ku}$ antigen $(1,2-0.6 \mu \mathrm{g}$ and 3, 4-1.2 $\mu$ g of Ku antigen): 1,3-DDE-AP DNA; 2, 4-BE-AP DNA

probably due to an easy ionization of these peptides under the analysis conditions.

The appearance of the Ku80 adduct with a lowered electrophoretic mobility characteristic for DDE-AP DNA can reflect the existence of two different modes of Ku80 binding with DNA (and, consequently, different points of interaction with the AP site) or the highly efficient cross-linking of DNA with another Ku80 isoform. Indeed, the lists of candidates for the samples N 1 and 2 include a Ku80 isoform with higher molecular mass (93464 Da). The biochemical properties of this isoform resemble those of the conventional Ku80, but it cannot fully replace $\mathrm{Ku} 80$ [9]. To discriminate these alternatives, we purified the $\mathrm{Ku}$ antigen from HeLa cells (see
«Materials and methods») to near homogeneity (Fig. 3) and then tested the ability of the purified protein to interact with two aforementioned types of AP DNA (Fig. 4). The patterns of cross-linking of two AP DNAs to the purified $\mathrm{Ku}$ antigen and cell extract proteins have the analogous set of products: more abundant $100 \mathrm{kDa}$ and less intensive $90 \mathrm{kDa}$ adducts for DDE-AP DNA (lanes 1,3 ) and $90 \mathrm{kDa}$ adduct for BE-AP DNA (lanes 2,4).

Conclusions. Thus, the $\mathrm{Ku} 80$ subunit of $\mathrm{Ku}$ antigen specifically interacts with the AP DNA structure with 5'- and 3'-dangling ends and forms a covalent adduct with an apparent molecular mass of $100 \mathrm{kDa}$ after the treatment with $\mathrm{NaBH}_{4}$. Further investigations are required to determine the role of these modes of the $\mathrm{Ku}$ antigen interaction with the AP sites. This type of damaged DNA structure can be used to monitor the binding activity of $\mathrm{Ku}$ antigen in the extracts of various human cells.

Funding. This work was supported by RFBR, projects 13-04-01426, 13-04-93107, GDRI program «From Molecular to Cellular Events in Human Pathologies», the RAS program «Molecular and Cellular Biology», and the Ministry of Education and Science of Russia, project 14.B37.21.0188.

Взаємодія Ки80 з апуриновими/апіримідиновими сайтами залежить від структури ДНК

А. А. Косова, С. Н. Ходирева, О. І. Лаврик

Резюме

Мета. Ідентифікація білка з екстракту клітин людини, який спеичфічно взаємодіє з апуриновим/апіримідиновим (AP) сайтом у складі часткового дуплексу ДНК, щзо містить виступаючі 5'- $i$ 3'-кінці та імітує кластерне пошкодження ДНК. Методы. Зшивання білка з АР-ДНК, опосередковане утворенням основи Шиффа, MALDI-TOF мас-спектрометрія, хроматографія і гель-електрофорез. Результаты. Білок клітинних екстрактів людиниа, який формує мажорний ковалентний адукт з АР-ДНК, щчо містить виступаючі кінці, ідентифіковано як субодиниия Ки80 Ки-антигену методом пептидного картування, заснованого на даних MALDITOF мас-спектрометрії. Показано, щуо Ки-антиген, виділений з клітин HeLa, формує ковалентні адукти, електрофоретична рухливість яких відповідає рухливості адуктів, утворених білками з клітинних екстрактів. Висновки. Субодиниия Ки 80 Ки-антигену може специифічно взаємодіяти з АР-ДНК, формуючи адукти, опосередковані утворенням основи Шиффа, електрофоретична рухливість яких залежить від структури кінщів ДНК. Розбіжності в електрофоретичній рухливості можуть обумовлюватися зииванням АР-ДНК з різними амінокислотними залишками білка, щзо в свою чергу може відображати різне розташування АР-ДНК у комплексі з Ки-антигеном. 
Ключові слова: Ки-антиген, апуриновий/апіримідиновий сайт, зиивання білок-ДНК, кластерні пошкодження ДНК.

Взаимодействие Кu80 с апуриновыми/апиримидиновыми сайтами зависит от структуры концов ДНК

\section{А. А. Косова, С. Н. Ходырева, О. И. Лаврик}

\section{Резюме}

Цель. Идентификация белка клеточных экстрактов человека, спеиифично взаимодействующего с апуриновым/апиримидиновым (AP) сайтом в составе частичного ДНК-дуплекса, содержащего выступающие 5'- и 3'-конщы и имитирующего кластерное повреждение ДНК. Методы. Сшивка белка с АР-ДНК, опосредованная образованием основания Шиффа, MALDI-TOF масс-спектрометрия, хроматография и гель-электрофорез. Результаты. Белок клеточных экстрактов человека, формирующий мажорный ковалентный аддукт с АР-ДНК, содержащей выступающие конщы, идентифицирован как субъединица Ки80 Ки-антигена методом пептидного картирования, основанного на данных MALDI-TOF массспектрометрии. Показано, что Ки-антиген, выделенный из клеток HeLa, формирует ковалентные аддукты, электрофоретическая подвижность которых соответствует подвижности аддуктов, формируемых белками клеточных экстрактов. Выводы. Субъединииа Ки80 Ки-антигена может специифично взаимодействовать с АР-ДНК, формируя аддукты, опосредованные образованием основания Шиффа, электрофоретическая подвижность которых зависит от структуры кониов ДНК. Различие в электрофоретической подвижности может быть обусловлено сшивкой АР-ДНК с разными аминокислотными остатками бел$\kappa a$, что может отражать различное расположение АР-ДНК в комплексе с Ки-антигеном.

Ключевые слова: Ки-антиген, апуриновый/апиримидиновый сайт, сшивка белок-ДНК, кластерные повреждения ДНК.

\section{REFERENCES}

1. Atamna H, Cheung I, Ames BN. A method for detecting abasic sites in living cells: age-dependent changes in base excision repair. Proc Natl Acad Sci USA. 2000; 97(2):686-91.

2. McCullough AK, Dodson ML, Lloyd RS. Initiation of base excision repair: glycosylase mechanisms and structures. Annu Rev Biochem. 1999; 68:255-85.

3. Georgakilas $A G, O$ 'Neill P, Stewart $R D$. Induction and repair of clustered DNA lesions: what do we know so far? Radiat Res. 2013; 180(1):100-9.

4. Ilina ES, Lavrik OI, Khodyreva SN. Ku antigen interacts with abasic sites. Biochim Biophys Acta. 2008; 1784(11):1777-85.

5. Khodyreva SN, Prasad R, Ilina ES, Sukhanova MV, Kutuzov MM, Liu Y, Hou EW, Wilson SH, Lavrik OI. Apurinic/apyrimidinic (AP) site recognition by the 5'-dRP/AP lyase in poly(ADPribose) polymerase-1 (PARP-1). Proc Natl Acad Sci USA. 2010; 107(51):22090-5.

6. Prasad R, Liu Y, Deterding LJ, Poltoratsky VP, Kedar PS, Horton JK, Kanno S, Asagoshi K, Hou EW, Khodyreva SN, Lavrik OI, Tomer KB, Yasui A, Wilson SH. HMGB1 is a cofactor in mammalian base excision repair. Mol Cell. 2007; 27(5):829-41.

7. Gullo C, Au M, Feng G, Teoh $G$. The biology of $\mathrm{Ku}$ and its potential oncogenic role in cancer. Biochim Biophys Acta. 2006; 1765 (2):223-34.

8. Biade S, Sobol RW, Wilson SH, Matsumoto Y. Impairment of proliferating cell nuclear antigen-dependent apurinic/apyrimidinic site repair on linear DNA. J Biol Chem. 1998; 273(2):898-902.

9. Koike M, Yutoku Y, Koike A. KARP-1 works as a heterodimer with $\mathrm{Ku} 70$, but the function of KARP-1 cannot perfectly replace that of Ku80 in DSB repair. Exp Cell Res. 2011; 317(16): 2267-5.

10. Fransson J, Borrebaeck CA. The nuclear DNA repair protein $\mathrm{Ku} 70 / 80$ is a tumor-associated antigen displaying rapid receptor mediated endocytosis. Int J Cancer. 2006; 119(10):2492-6. 